Article

\title{
Jewish Spatial Practices in Barcelona as Claims for Recognition
}

\author{
Julia Martínez-Ariño \\ Department of the Comparative Study of Religion, University of Groningen, 9712GK Groningen, The Netherlands; \\ E-Mail: j.martinez.arino@rug.nl
}

Submitted: 12 March 2020 | Accepted: 19 June 2020 | Published: 20 August 2020

\begin{abstract}
In this article, I argue that the spatial practices of the contemporary Jewish organisations in Barcelona's medieval Jewish neighbourhood represent claims for public recognition. As a small and quite invisible minority within the diverse city population, Jewish groups increasingly claim that their presence in the city should be recognised by political authorities and ordinary citizens alike. They do so through a series of spatial practices around the medieval Jewish neighbourhood, which include (1) heritage production, (2) the renaming of streets and (3) the temporary marking of urban spaces with Jewish symbols. I have grouped these practices under the umbrella concept of 'place-recovering strategies' because all of them attempt to 'recover' the lost urban environments inhabited by their Jewish predecessors before they were expelled from the Iberian Peninsula in the fourteenth and fifteenth centuries. By recovering I do not mean a mere passive restoring of urban spaces and places but rather a creative process in which historical narratives and myths of the past play a crucial role. Drawing on qualitative fieldwork, I argue that these place-recovering strategies are part of a quest for the visibility, legitimacy and recognition of Jews.
\end{abstract}

\section{Keywords}

Barcelona; heritagisation; Jewish communities; place-recovering; recognition; urban spaces

\section{Issue}

This article is part of the issue "Religious Minorities and Struggle for Recognition" edited by Christophe Monnot (University of Lausanne, Switzerland/University of Strasbourg, France) and Solange Lefebvre (University of Montreal, Canada).

(C) 2020 by the author; licensee Cogitatio (Lisbon, Portugal). This article is licensed under a Creative Commons Attribution 4.0 International License (CC BY).

\section{Introduction}

Across European cities, old Jewish neighbourhoods have become sites of struggles for the recognition of Jewish minorities. The Council of Europe has pushed for the role of the Jewish people in European history to be acknowledged and Jewish heritage preserved. Research has taken up the increasing public interest of Jews and non-Jews in the reconstruction and reinvention of Europe's Jewish past and culture (Gruber, 2002; Lehrer \& Meng, 2015). In this article, I examine the spatial practices of Jewish organisations around the old Jewish neighbourhood of Barcelona.

Barcelona had a rich cultural, economic and religious Jewish life in the Middle Ages until the 1391 pogrom erased all traces of communal life (Rich Abad, 1999). My research asks how contemporary Jewish organisationsincluding religious communities, cultural and heritage associations and small Jewish-owned businesses-in Barcelona interact with the space and memory of the old Jewish neighbourhood and how this interaction plays out in the contemporary claims for public recognition of this minority. In so doing, I contribute to a more exhaustive understanding of the emplacement and quest for recognition of minority religious groups in contemporary European urban contexts.

This intersection between religion and space and, in particular, the spatial strategies of minority religious groups in urban settings have attracted the interest of scholars of religion. In their work, Vásquez and Knott (2014) and Eade (2012) analyse the influence of religion in immigrant place-making strategies in their destination cities. More recently, Becci, Burchardt, and Giorda (2017) have proposed a typology of spatial strategies for studying how religious groups, both immigrant and non-immigrant, strive to find a place in the city. The au- 
thors distinguish between place-keeping, place-making and place-seeking strategies.

Although this typology makes a very significant contribution to the study of urban religion and its spatial regimes, I argue that it fails to capture the strategies of religious groups that were formerly expelled from a territory and are now 'coming back' to those spaces and 'recovering' them after a period of absence. This is the case for Jewish communities in many European cities since the Second World War, but also previously for the Jewish communities that were expelled from the Iberian Peninsula in 1492. Jews in Spain, and the European Jewry more broadly, therefore occupy a special position: They are neither established majority religions 'keeping' their places in urban contexts, nor entirely new immigrant religions 'making' new religious places, nor urban dwellers 'seeking' spiritual places.

Drawing on empirical research, in this article I propose a fourth category that I call 'place recovering.' By place recovering I refer to the spatial strategies and practices of minority groups that, having been expelled from a certain urban context, draw on reconstructions of the past in order to recover the lost urban environments of their predecessors or themselves. One might also adopt a broader understanding of this concept to include the engagement of diasporic communities in the recovery of places without their necessarily having experienced expulsion or persecution. Place-recovering strategies thus include a variety of practices whereby these groups seek to re-appropriate and re-signify places that were of significance to those communities in the past as a means to claim recognition.

Giving greater centrality to the symbolic, discursive and aspirational dimensions of religious groups' spatial strategies (Burchardt \& Westendorp, 2018), this fourth category allows these practices to be distinguished from those involved in the making of entirely new places. While this conceptualisation acknowledges that place recovering is not merely a passive restoring of past urban spaces and places, but rather a creative and constructive process, I argue that it also entails a relationship to urban space that is different from one that exclusively creates completely new places. Place-recovering strategies appeal to, and produce, historical narratives and myths that provide meaning and grant historical legitimacy to the current struggle and aspiration for visibility and recognition.

The recovery of the Barcelona call (the Catalan word for a medieval Jewish neighbourhood) through the spatial practices of diverse Jewish initiatives, including cultural and heritage associations, businesses and some religious communities, must be understood against the background of a wider international interest in that past and a proliferation of memorialisation projects. Initially led by state institutions and non-Jewish organisations, for some years now these projects have also taken their lead from Jewish groups (Clark, 1999). My interest in this article is in the strategies pursued by the latter in an attempt to claim their voice and gain public recognition.
This research is a case study that combines semistructured interviews, document analysis and spatial observation in Barcelona. I interviewed six representatives of the local Jewish organisations involved in the medieval Jewish neighbourhood. I interviewed them not as individual Jews but as representatives of organisational efforts around the call, namely two cultural and heritage associations, two small business and two religious communities. Since I conducted my PhD research on the Jewish communities of Catalonia (Martínez-Ariño, 2012a), I could access these persons easily. Some of them I had interviewed for my doctoral research; with others I had contacts in common. Thus, while I am an outsider-not being a Jew myself-I have been in close contact with the Jewish institutional milieu for some years. The interviews took place in a relaxed atmosphere both for my interviewees and myself. All interviews lasted between 40 and 90 minutes, were audiorecorded and transcribed literally. I conducted an inductive thematic analysis to identify the most salient topics relevant to my research question and objectives that emerged in these conversations.

I walked along the streets of the call, including Carrer del Call, Carrer de Marlet, Carrer San Honorat and Carrer de Salomó Ben Adret and observed their official labelling as parts of the old Jewish neighbourhood. I also participated in one of the tours for Jewish tourists in the neighbourhood, where I got familiar with the history of the quarter narrated from a Jewish standpoint and observed the inscriptions in Hebrew in some buildings in the area. I was also shown around two medieval Jewish houses that currently host Jewish cultural and touristic initiatives. Finally, I collected a substantial number of documents, including websites, Facebook posts, municipal records, newsletters and public speeches by members of the city's Jewish communities and cultural associations, and news items in local newspapers related to the call.

\section{Heritagisation, Place Naming and Place Marking}

In the sociology of religion, authors have theorised the spatial strategies of religious groups in urban contexts of religious super-diversity (Becci et al., 2017). Place-keeping, place-making and place-seeking strategies refer to the ways in which religious groups interact with urban spaces. Place keeping refers to the strategies used by dominant Christian churches to preserve their public presence and significance at a moment when their numerical relevance and hegemony are at stake. In contrast, place-making strategies encapsulate the practices of diasporic and immigrant communities in creating their own new religious places in urban contexts. Thirdly, place-seeking strategies, mostly linked to new spiritual initiatives, refer to strategies "that produce ephemeral and evanescent presences" in cities (Becci et al., 2017, p. 85). This analysis, however, has omitted what I have called 'place-recovering strategies,' as defined above. As I argue below by drawing on the 
empirical case of Barcelona and the developments observed around its medieval Jewish neighbourhood, spatial strategies of place recovering mainly materialise in practices of (1) heritagisation, (2) place naming and (3) place marking.

An interest in the socio-political, cultural and economic dimensions of heritagisation processes, as well as their implications, risks and contestations, is growing in the social sciences (Graham, 2002; Zubrzycki, 2012). In the sociology of religion, the focus is on the contested nature of religious heritage, particularly in diverse contexts (Astor, Burchardt, \& Griera, 2017). Research on the recovery of Jewish material and architectural heritage has mostly focused on its touristic and economic uses and conservation policies (Krakover, 2012, 2013; Negussie, 2007; Petrevska, Krakover, \& Collins-Kreiner, 2018) and less on the role of local Jewish communities in reclaiming these 'lost' places (Corsale, 2017). By focusing on the discursive and spatial practices of Jewish organisations around heritage, I contribute critical insights on bottomup heritagisation dynamics.

Critical toponymy studies understand the naming of places as practices of remembering certain past events and stories, which are key to the social production of space and the creation of spatial identities (Rose-Redwood, Alderman, \& Azaryahu, 2010). The focus on the "cultural politics of naming" allows the negotiations and contestations of naming processes to be captured as part of "struggles for legitimacy and visibility" (Rose-Redwood et al., 2010, p. 457). Place names mark the relationships and emotional attachments between people and places, "even in the face of physical alienation from these very same places" (Rose-Redwood et al., 2010, p. 458; Shoval, 2013). This article examines place naming as a claim for recognition of both a tragic and flourishing past by Jewish organisations in Barcelona.

Finally, the notion of "signs of the sacred" (Sinha, 2016, p. 470) has been coined to study the marking of urban secular spaces with religious symbols, objects, bodies and practices put up, recognised and used by practitioners. These signs can be permanent or temporary markers that create a sort of sacred 'microcosm' and demarcate the boundaries that separate that which is inside from that which remains outside (Saint-Blancat \& Cancellieri, 2014; Umashankar, 2015).

Drawing on these theoretical insights, I argue that heritagisation, place-making and place-marking practices are means of claiming public recognition that draw on history as a source of legitimacy. In doing so, I refine conceptual tools to analyse the spatial dynamics of minority religion and its recognition in contexts of diversity.

\section{3. 'Recovering' the Barcelona Jewish Call}

Barcelona's contemporary Jewish presence remains widely unnoticed (Martínez-Ariño, 2016). While the Jewish population in Catalonia-and Barcelona as its capital city-is estimated at a maximum of 8000 Jews
(Rozenberg, 2010), only about half of them are affiliated to one of the five Jewish communities (one ultraOrthodox, two Orthodox, one Masorti and one Reform). With all five being located far from the old Jewish neighbourhood, their engagement with it is rather limited. The presence of this highly diverse populationideologically, religiously and in terms of their geographical backgrounds (Martínez-Ariño, 2012b) -in the call is limited to a few religious, cultural and heritage associations and two small businesses that operate there. However, as far as my interviewees could tell me, no Jewish family lives there now.

Despite this invisibility, an increasing interest in Barcelona's Jewish past is apparent among Jews and non-Jews, tourists and local residents alike. This trend is also present in other European cities (Corsale, 2017; Corsale \& Vuytsyk, 2018). In this section, I present examples of spatial practices of Jewish religious, cultural and heritage associations and small businesses that have recently taken place in and around the medieval Jewish neighbourhood, and which I group under the concept of place-recovering strategies. The Jewish organisations behind these initiatives come from very different ideological backgrounds. Some are secular organisations that engage with the neighbourhood from a cultural and heritage perspective, whereas others, in particular the local branch of Chabad-Lubavitch, do so by organising religious rituals for locals and tourists. However, they all share the reference to the Jewish past of the neighbourhood in their aspirations for the current Jewish presence in the city to be known and publicly recognised. Moreover, their engagement with the neighbourhood is not so much based on references to a particular Sephardic ancestry, which they do not claim directly, but rather to a broader pan-Jewish identification as a people.

While the neighbourhood has been an object of heritage and tourism policies already since the creation in 1993 of the countrywide project Caminos de Sefarad: Red de Juderías de España (Routes of Sepharad: Network of Spanish Jewish Quarters), in this article I focus exclusively on the initiatives of Jewish organisations. The latter are a form of appropriation of the space from within the Jewish milieu that differ significantly from the above-mentioned touristic project, promoted by twentytwo Spanish municipalities. From this perspective, next to an economic interest, the neighbourhood is a site where Jewish organisations claim public recognition, as both a historical and a contemporary minority. I have classified their practices in three types: (1) heritagisation practices, (2) place-naming practices and (3) placemarking practices.

The first type includes the (polemic) restoration of a former medieval synagogue, the creation of a Jewish cultural centre, and the development of an alternative touristic programme by Jewish entrepreneurs. The second type includes the recent renaming of a street after a medieval rabbi. The third type is more heterogeneous and encompasses the celebration of Jewish religious and 
cultural festivals in public spaces, e.g., the construction of a sukkah and the lighting of the hannukiah in two public squares, and the celebration of the Barcelona Jewish Film Festival and the European Day of Jewish Culture. All these practices, some permanent, others temporary, contribute to re-appropriating an urban space in which Jewish organisations feel disinherited due to heritage policies and private economic practices that, for the most part, exclude them.

\subsection{Place Recovering through Heritagisation}

In 1996, a Jewish citizen of Barcelona acquired the ground floor of a house in the call, as this was the position where the major medieval synagogue of the city was supposedly located. Its website presents the spaceopen as a museum since 2002-as a project that aims to "rescue from oblivion a long period of the history of Catalonia through the rehabilitation of the old synagogue space" (Greater Synagogue of Barcelona, 2020). While controversy has surrounded the location, as new historical research shows that the synagogue was probably located in the adjacent building (Caballé \& Gonzàlez, 2002; Casals \& Jáuregui, 2015), this could be considered the first step taken by Jews in the contemporary heritagization of the Jewish call of Barcelona.

A more recent development is the opening of Casa Adret (Adret House) in 2018. This initiative became a local hub of Jewish cultural production. Run by Mozaika, a Jewish cultural association, with support from the European Association for the Preservation and Promotion of Jewish Culture and Heritage (EAPJ) and other smaller public and private contributions, Casa Adret is located in a majestic house in the call. A Jewish family owned the building in the Middle Ages, as the municipal cadastral records and a mezuzah door hole indicate. The project partly mirrors a similar one instituted in the Catalan city of Girona in 1992-the Bonastruc ça Porta Centre, run by the Patronat Call de Girona, which includes the Museum of Jewish History and the Nahmanides Institute for Jewish Studies-to which I refer in Section 3.2. By conducting research on the city's Jewish past, and organising talks, conferences, concerts, tours and gastronomic activities that aim to recover this past, Casa Adret aims to produce alternative heritage discourses about the neighbourhood. Its primary public is the local population, both Jewish and nonJewish. However, Casa Adret tries to distinguish itself from the most popular tourist companies by proposing a 'distinguished' cultural product that offers what its members claim to be a more accurate narrative of history.

A third example of heritagisation is the entire touristic programme that local Jewish entrepreneurs have developed as an alternative to the official offer. Call Barcelona Wines \& Books is a Jewish-themed shop and cultural centre located in one of the houses of the old Jewish neighbourhood and run by the international movement Chabad-Lubavitch. Opened in 2009, the shop sells a variety of Jewish products, including kosher wines, books and kippot, and organises cultural activities and 3D tours around the neighbourhood. It is primarily addressed to the Jewish public: its Facebook page refers to it as a means "to know your roots and renew your identity" (Call Barcelona Wines \& Books, 2013). The Urban Cultours project is a business started by a Jewish architect in 1997, who states on her website that "our memory must be kept alive, brought back after 600 years of oblivion" (Urban Cultours, 2002). This entrepreneur organises tours that include both visits to past Jewish places and participation in current Jewish life and events, including Shabbat services. This alternative offer is mostly addressed to Jewish tourists, who have increased in numbers in recent years, impelled by new lowcost air connections between Tel Aviv and the cities of Barcelona and Lleida, and tourist and commercial agreements between the Catalan and Israeli governments.

\subsection{Place Recovering through Place Naming}

In 2018, one of the streets in the Jewish call was renamed after a medieval rabbi from the city, Salomó Ben Adret (after whom Casa Adret is also named). Ben Adret, who was born around 1235 and died around 1310, was one of the most important Talmudic masters and commentators, and leader of the medieval Barcelona Jewish community. As a Talmudic scholar, he gave responses to questions that individuals, families and the rabbinic tribunals posed concerning everyday practical matters of the lives of Jews and their interaction with Christians (Feliu, 2003, 2009; Hames, 2010). The re-naming of the street-resulting from claims made in a letter to the mayor in 2017 by all four local Jewish communities at that time and some associations-after previous unsuccessful attempts, had a clear reparative aim. The street was formerly called San Domènec del Call. San Domènec refers to the feast day of this saint on 5 August. This was the day when a pogrom against the Jewish population living in the Barcelona Jewish quarter in 1391 took place (Feliu, 2005; Pons i Casacuberta, 2010). As the 2017 letter to the mayor indicated, the name change was an initiative to commemorate the lives of the citizens who had been killed in that violent event, and to protect convivencia. In their own words: "We cannot allow the infamy of the 1391 pogrom to be perpetuated in the streets of the city and the memory of the victims-all citizens of Barcelona-to be underestimated" (letter to the Mayor from 2017, shared via private communication with some Jewish organisations). The district council approved unanimously the request to remove the derogatory name and acknowledged the need for historical reparation (Ajuntament de Barcelona, 2018a). In the council session, the representative of the Jewish organisations who intervened indicated that they had proposed Salomó Ben Adret not only because he was an internationally renowned Talmudic scholar, but also because he "represents plurality and coexistence 
within medieval Judaism, reconciling in our city the various opposing tendencies, between rationalists and mystics" (Ajuntament de Barcelona, 2018a, p. 42). Two members of the municipal government and a few members of the Jewish organisations participated in the public uncovering of the plaque in November 2018, an event reported in several local media.

From the perspective of political semiotics, the renaming of the street must be considered a quest for justice through the cultural and political recognition of a contemporary minority and of its persecution in the past. Commemorative place-naming practices connote symbolic functions and contribute to "the cultural production of shared past" (Azaryahu, 1996, p. 311). In Barcelona, Jewish organisations and the municipal government see the change in the street name as a form of historical reparation that recognises the importance of minorities. Moreover, it makes the cultural and political representation of a contemporary minority more visible, thereby "establishing who has a right to the city in public spaces" (Mitchell, 2003, as cited in Rose-Redwood et al., 2010, p. 465).

\subsection{Place Recovering through Place Marking}

Next to these rather stable elements, Jewish organisations also hold more ephemeral religious and cultural practices in the public spaces of the old neighbourhood. I will present four of them: the construction of a public sukkah and the public lighting of the hannukiah, on the one hand, and the Barcelona Jewish Film Festival and the European Days of Jewish Culture 2018, on the other. These open-air practices mark and render visible the spatial presence of today's Jewish organisations in the neighbourhood.

The construction of a sukkah in Placeta del $\mathrm{Pi}$ and the celebration of Hannukah in Plaça Sant Jaume are two spatial practices that temporarily mark the space as Jewish and invest it with religious meanings. The public sukkah was constructed in 2018 for the first time after obtaining the permission and logistical support of the municipality. The event was promoted and organised by Chabad-Lubavitch with the aim of providing locals and tourists with the possibility to celebrate the festival of Sukkot. Their aspiration was to place Barcelona at the level of other global cities in terms of public Jewish life. A member of a Reform Jewish community, ideologically closer to the municipal government, initiated the first contact with city officials in a rather informal way (personal interview, 29 October 2018). This piece of temporary religious architecture changed the configuration of the square and endowed it with religious meaning. The event was celebrated widely by members of the Jewish communities involved and the municipal government as being the "first sukkah [constructed in Spain] since the Inquisition" (Pin, 2018). The emphasis placed by the Jewish representatives on its historic character and on the need for historical reparation was strategic in achieving municipal support. In one of the leaflets produced to inform neighbours about the religious festivals taking place in that area, the district council explains the festival of Sukkot and emphasises the historic character of the celebration: "The festivity of Sukkot 2018 in Barcelona will install the first public sukkah in the whole country" (Ajuntament de Barcelona, 2018b). Moreover, the then left-leaning municipal government considered this and other religious events an expression of the cultural and religious diversity of the city and a sign of the richness that this diversity brings to it (Ajuntament de Barcelona, 2018c).

Similarly, the public lighting of the hannukiah in the square where the City Hall and the seat of the Catalan government are located marks the space temporarily as sacred. By way of the spatial configuration of objects, including a big candelabrum, and a ritual of lighting candles, singing religious songs and dancing, the space becomes Jewish and religious. Again here, Chabad-Luvabitch, and its standardised display of Hannukah celebrations in public throughout the globe (Endelstein, 2017), is the main actor. While its linkage with the Sephardic tradition is rather weak, Chabad-Luvabitch too emphasises the connection of this public celebration with the tragic past of the city. As one of my interviewees, member of Chabad, put it:

The fact of celebrating a festival such as the Festival of Lights with Christmas simultaneously in the same part of the city is like a reconciliation with the past, with the trouble that took place at the time of the Inquisition.

These two examples of "doing Jewish space" (Brauch, Lipphardt, \& Nocke, 2016, p. 2) temporarily by inserting religious symbols and celebrations in a public square transform an iconic space of the city for participants, passers-by and regular pedestrians alike, thereby reinforcing the emplacement of the Jewish minority in this particular area of the city. However, not all Jewish organisations, including heritage associations and some religious communities, agree with Chabad's 'religionizing' approach, whereby public space is signified and marked as religious (Dressler, 2019). Therefore, participation in these events of progressive and secular Jews, as well as of members of other Jewish communities who 'compete' for the same public with Chabad, tends to be rather scarce.

The Barcelona Jewish Film Festival is a wellestablished event organised since 1999. It is the main activity representing the city in the Red de Juderías de España project. After providing a brief summary of the rich and tragic history of the Jews who lived in the call, the website of the festival presents its aims, i.e., "to place Jewish culture in the cultural scene of the city" and "to show the intercultural nature of the Jewish people" (Festival Cinema Jueu, 2019). Every year, this two-week event screens a wide variety of Jewish-themed films pro- 
duced in Spain and abroad. While most of its activities take place in cinemas and projection rooms, between 2004 and 2015, its official opening took place yearly in one of the squares of the call. The selection of this spot was made to show the city population that this had been a space inhabited by Jews in the past, thereby bestowing the event with more 'Jewish texture,' that of the stones and buildings of the old Jewish neighbourhood. As the director of the festival told me, choosing to screen films in a public square, at a time when the city's Jewish past was widely unknown:

Was a way of saying: We are screening films here because there were riots here in $1391 \ldots$, there was a Jewish neighbourhood here, Jews lived here.....Many important figures came out of the Barcelona Jewish community and all of a sudden, in one day, they were kicked out and that was it, 400 or 500 years without a Jewish institutional presence. (personal interview, 29 October 2018)

The European Day of Jewish Culture 2018 is a panEuropean project that aims to offer "the broader public the possibility to discover several aspects of Jewish heritage and get acquainted with Jewish culture and traditions" (EAPJ, 2018). The 2018 edition in Barcelona consisted of a series of cultural events organised around the theme of 'storytelling,' a component of Jewish oral tradition used to disseminate historical heritage. Theatrical performances reviving the medieval and recent Jewish past of the city through its historical characters filled the streets of the Jewish neighbourhood with living Jewish life. Organised by Casa Adret with the financial support of the European Council and the Patronat Call de Girona-a publicly funded and independent municipal board in the City of Girona that aims to renovate and promote the historical Jewish neighbourhood of that Catalan city-the event aimed to disseminate Jewish culture in entertaining ways.

As should be clear by now, I am not arguing that place-recovering strategies consist of practices merely restoring 'the past' as if it were possible to bring it back. A clear example of this is the fact that one of the organisations actively referring to that past, Chabad Lubavitch, is a modern movement that claims to represent Jewish authenticity. The reconstruction and recreation of that past and its urban space is designed to "transform an abstract absence into a palpable presence" (Richards, 2005, p. 618). For Chabad, as well as for the other Jewish organisations involved, 'the Jewish past' of Barcelona serves as a discursive tool to frame their current activities. These activities transform the abstract absence into the palpable reality of the neighbourhood now.

In a sense, all these examples of the appropriation of a certain part of the city for community purposes could be considered practices of place making, whereby a religious minority makes new places in the city (Becci et al., 2017). However, they are, I argue, qualitatively dif- ferent. Some Jewish organisations of Barcelona are not making some of their places anew anywhere in the city but are actually focusing on a particular part of the city that had been the Jewish neighbourhood in the past. Therefore, by 'inhabiting' these spaces, these Jewish organisations are doing two things, imbuing the neighbourhood with contemporary Jewish references and drawing on the Jewish history of the place to claim their historical belonging to it. More specifically, by "marking a space as a heritage site" through contemporary uses, the Jewish groups are providing "a 'second life' for that space" (Kirshenblatt-Gimblett, 1998, p. 149). In turn, Jewish-signified spaces are being used to bestow content and meaning on this minority and to give historical legitimacy to its claims for recognition. As one of the main persons responsible for Casa Adret told me, "the fact of being in the call is symbolically very important....The fact of being in the old Jewish neighbourhood creates a link between the contemporary Jewish community and the history of the city" (personal interview, 31 October 2019).

The examples above show the importance of the temporal dimension involved in recalling the past in order to legitimise the present and claim recognition as an urban community, also for the future. Three temporalities converge: (1) the recovery and reconstruction of both an idealised past of flourishing Jewish life and the memory of a "history of pain" (Richards, 2005, p. 618), (2) the attempt to make Jewish life more visible in the present and $(3)$ the aspiration of a future with full recognition. In other words, these spatial practices reflect the ideals and aspirations of a group in relation to its presence, visibility and recognition in the city that differ from both the current state of things and the memories of the past.

\section{Recovering the Call as a Claim for Recognition}

In what follows, I examine the motivations that underlie and discourses that justify the spatial strategies of the Jewish organisations that I have examined. As indicated previously, I am interested in their organisational motivations rather than in their individual reasons, although the two may coincide at times. These range from an affective relationship and emotional attachment to the place, to the appropriation of the space for economic, political and memory reasons. Although intra-communal struggles around community representativeness in front of city authorities also play a role in the undertakings of these organisations in the call, these are beyond the scope of this article.

The most evident motivation for Jewish organisations to install themselves in the old Jewish neighbourhood is economic. The call is a good site for a "selling of the past" (Ashworth, Graham, \& Tunbridge, 2007, p. 31). Some Jewish organisations, such as Call Barcelona Wines \& Books store and its 3D tours, address themselves mostly to Jewish tourists from Israel and the US. Others aim to occupy the niche of a more exclusive touristic offer for locals and people with a 'real' interest in heritage 
and history. This is the case of the tours and culinary experiences offered by Casa Adret.

However, based on the discourses of my interviewees, I argue that, economic interests aside, their investments in these practices are also part of their struggle for recognition in the space of the city. In a highly diverse context like Barcelona, where historical Judaism was erased and contemporary Judaism is still invisible today (Martínez-Ariño, 2016), heritage production can serve to validate and legitimise the presence of this minority in the city. "The Jewish neighbourhood is part of the DNA of the city," claimed one of the Jewish entrepreneurs of the call. The representative of another association claimed their role as key actors within the local social fabric in protecting the neighbourhood from its mass touristic exploitation and related gentrification. In so doing, they portray the Jewish presence as inherent and essential to the very nature and continuity of the city and neighbourhood, despite their absence for a period of over 500 years.

Heritage conveys an "idea of continuity" that validates the contemporary Jewish presence. Put differently, heritage production fulfils "a need to connect the present to the past in an unbroken trajectory" (Graham, 2002 , p. 1008). For some of the Jewish associations in the call, recovering the past is a means to show continuity with the present and make contemporary Jewish organisations visible. This function of continuity-building is particularly important in contexts where the connections of a people to a place have been cut, as is the case for the Jewish communities expelled from Spain in the fourteenth and fifteenth centuries. Their organisers consider contemporary initiatives a way of dispelling the interruption, by five hundred years of darkness, of the alleged convivencia that existed before the 1391 attacks, as one of my interviewees put it (personal interview, 29 October 2018). The culinary routes and the celebration of public religious festivals attempt to recreate and recover the places from which these traditions were cut. Simultaneously, they show that those culinary traditions and religious festivals are again part of the contemporary life of the city. Moreover, marking the space as Jewish by lighting the hannukiah and constructing the sukkah is a strategy to remind not only tourists, but also the rest of the city's population, of Barcelona's Jewish past and, more importantly, of the contemporary Jewish presence. Even though Jews no longer live in the call, this is a way of "asserting the community's presence in city affairs in the present" (Clark, 2007, section 4.7). Jewish actors want to prevent Jews from being imagined as 'relics' or 'fossils' of the past by promoting an image of a population that is alive, as also shown by Corsale and Vuytsyk (2018) for the Ukrainian city of Lviv.

Relatedly, a sense of duty to historical memory in order to fight the "collective amnesia" (Clark, 2007, section 1.1.) around Spain's Jewish past is present in the discourses of my interviewees. Many of the activities and practices analysed attempt to memorialise an absence by making it palpable in the present (Richards, 2005). In particular, the change in the street name epitomises this struggle for recognition of the past suffering of the local Jewish communities that were devastated by the 1391 pogrom. It is an endeavour to recover and memorialise that which was tragically erased from the urban landscapes of many European cities. Closely connected to this sense of the duty of memory is the emotional attachment to a place (Kearney \& Bradley, 2009), which is both a memory-holder of that absence and a way to make visible and normalise the contemporary Jewish presence. One representative of a Jewish community put it this way:

We are now in the 21st century, and we have a connection with these [medieval] Jews. We feel an emotional connection to the space, to what they did, because they were Jews, and to the space because now we share again this space in Barcelona, this small corner with the four streets that remain there. So, it is the recuperation of memory in order to explain and normalise the Jewish life and in order for institutions to talk again about Jews and that they make changes, such as the change they made removing the old street name. (personal interview, 29 October 2018)

Finally, the practices of these Jewish organisations are also an attempt to claim a voice and space of their own in the heritage industry. In the tour addressed to Jewish tourists in which I participated, the guide and Jewish entrepreneur introduced herself saying that she decided to start those tours "because it was time for Jews, as a minority, to take the microphone and speak for ourselves." When I interviewed her after the tour, she told me that she felt the heritage industry "was speaking of Jews as if they did not exist, as if after 1492 there was a glaciation period and we disappeared from the map. But Jews remained and we are back!" (personal interview, 30 December 2019). Through their initiatives, Jewish actors in the call challenge the "authorised heritage discourse" (Smith, 2006, p. 11), which in the words of this touristic guide "has appropriated the historical account" (personal interview, 30 December 2019). Moreover, as the representative of another Jewish heritage association put it, the official heritage discourse "misrepresents Jews and reproduces prejudices against them" (personal interview, 30 October 2018).

Like in other European cities, where rather small Jewish minorities are suspicious of the strategies of governments and economic stakeholders (Corsale, 2017), Jewish actors in Barcelona mistrust the political and economic management of the Jewish heritage. Through the subversion of official narratives, Jewish actors challenge their marginalisation and the "dispossession and disinheritance" that heritage production inevitably creates (Ashworth et al., 2007, p. 39). As a representative of a Jewish community put it: 
Other members and I feel a bit attacked with this topic because of the shameless utilisation [of the Jewish heritage by authorities] and not counting on living Jews. "We are only interested in stones, not in living Jews"....They [non-Jewish heritage actors] have to be respectful with traditions and customs. (personal interview, 29 October 2018)

Jewish actors present themselves as necessary to heritage by making claims to authenticity. They claim the value of their emic knowledge and 'profound experience' as something that is exclusive to them, something which governmental agencies and non-Jewish touring companies cannot provide. This argument of authenticity is twofold: on the one hand, it refers to some sort of historical continuity, whether real or imagined, with the past, and, on the other hand, it entails a normative assumption about a specific quality of the emic experience (Charmé, 2000). Representatives of different Jewish initiatives share this desire to show the experiential dimension as an added value. As one of them told me, Jewish actors play the role of providing the Jewish experience 'first hand' (personal interview, 31 October 2018), not like the technical and historical knowledge provided by non-Jewish specialists. By 'raising' their voice in the heritage sector, Jewish organisations claim that they be considered and recognised not only as 'objects' but also as 'subjects' of memory.

\section{Conclusion}

Drawing on conceptual tools from the sociology of religion, critical heritage studies and critical toponymy studies, in this article I have expanded the typology of religious groups' urban spatial strategies in contexts of religious super-diversity proposed by Becci et al. (2017). Based on an analysis of the spatial practices of some contemporary Jewish organisations of Barcelona in relation to the city's medieval Jewish neighbourhood, I have argued that, next to place-keeping, place-making and place-seeking strategies, a fourth set of strategies, which I call place-recovering strategies, should be added to the typology. This improves our understanding of the ways in which minority religions claim the recognition of their presence in contemporary urban contexts through their spatial practices. This addition is relevant because it captures a particular relationship to urban space that is neglected by the other three types, yet is of particular relevance in the contemporary European context. Research in other European cities, e.g., Bucharest and Lviv, shows similar attempts of Jewish stakeholders to be recognised and included in Jewish heritage practices (Corsale, 2017; Corsale \& Vuytsyk, 2018), indicating that placerecovering strategies are not exclusive to Barcelona.

In certain cases, place-recovering practices could be a part of a broader place-making strategy of a minority group, just like place-making practices can be a part of a broader strategy of majority religions to keep their place
(Becci et al., 2017). I would argue, however, that the recovery of places is not per se aiming at making a new place for a group to settle. A place-recovering strategy could be aimed solely at recognising the dispossession of a group from a place without it leading to the settlement of that group there.

Place-recovering strategies materialise in at least three types of practices: (1) heritagisation practices, (2) place-naming practices and (3) place-marking practices. Majority churches also turn to heritage discourses to keep their place and immigrant religious groups use place-marking practices, e.g., urban religious festivals, to make new places (Becci et al., 2017; Saint-Blancat \& Cancellieri, 2014). However, I argue that in relation to the recovering of places these practices have a particularity: They draw on the historical meaning of certain spaces and buildings and draw on mythical views of the past to legitimise claims for past and present recognition. In Barcelona, Jewish organisations claim their belonging and historical and emotional connections to the space of the call, thereby making their presence in the city more visible and legitimate. Thus, my analysis has shown that this neighbourhood is a site of struggle for public recognition. More research should be done on the internal community struggles and representativeness claims that also play out in the engagement of these organisations with this urban space.

The heuristic potential of the concept of place recovering can be extended beyond the specific analysis of the European Jewry. It can also serve analyses of other cases where historical or contemporary persecution or forced displacement followed later by return may influence the relationship of religious groups to the spatial regimes of cities. This would be the case with the attempts to reconstruct shrines, mosques and other sacred buildings of different religious traditions in post-war Bosnia-Herzegovina (Sells, 2003), indicating that strategies for recovering a space exist beyond the specific case of Jewish populations. Moreover, although I conceived of this notion as a tool for analysing a particular type of relationship of religious groups to urban spaces, in a broader conception place-recovering strategies and practices could also be used in examining diasporic engagements with a particular place that do not necessarily involve persecution or displacement. The term could be used to examine cases of rather different qualities such as the return and recovery of places significant to slavery by populations descended from enslaved persons (Richards, 2005). In any case, place-recovering strategies are related to pasts of expulsion, dispossession, disinheritance, displacement, persecution, eviction, flight or migration of a particular religious or ethnic minority from a specific place.

\section{Acknowledgments}

I would like to thank my colleagues of the "Ethnographies of Religion and Secularity" reading group at the 
University of Groningen for their thorough feedback on an earlier version of this article. The article was based on a paper I presented at the 35th Conference of the International Society for the Sociology of Religion, held in Barcelona in 2019, where I also got very valuable comments. I am also grateful to Lucy Spoliar for doing the language editing of the text. I would finally like to thank the editors of the thematic issue and the three anonymous reviewers for their constructive critique.

\section{Conflict of Interests}

The author declares no conflict of interests.

\section{References}

Ajuntament de Barcelona. (2018a). Ciutat Vella aprova canvi de nom del carrer Sant Domènec del Call per Salomó Ben Adret [Ciutat Vella approves the name change of carrer Sant Domènec del Call for Salomó Ben Adret]. Servei de Premsa. Ajuntament de Barcelona. Retrieved from https://ajuntament. barcelona.cat/premsa/2018/07/17/ciutat-vellaaprova-canvi-de-nom-del-carrer-sant-domenec-delcall-per-salomo-ben-adret

Ajuntament de Barcelona. (2018b). El Sukkot per primer cop a Barcelona [Sukkot for the first time in Barcelona]. Ajuntament de Barcelona. Retrieved from https://ajuntament.barcelona.cat/ciutatvella/ ca/noticia/el-sukkot-per-primer-cop-a-barcelona_ 708976

Ajuntament de Barcelona. (2018c). Les comunitats jueves de Barcelona celebren l'encesa de llums de Hanukkà [Barcelona Jewish communities celebrate the lighting of the Hannukah candles]. Ajuntament de Barcelona. Retrieved from https://ajuntament. barcelona.cat/oficina-afers-religiosos/ca/noticia/lescomunitats-jueves-de-barcelona-celebren-lencesade-llums-de-hanukka_745318

Ashworth, G. J., Graham, B. J., \& Tunbridge, J. E. (2007). Pluralising pasts: Heritage, identity and place in multicultural societies. London: Pluto Press.

Astor, A., Burchardt, M., \& Griera, M. (2017). The politics of religious heritage: Framing claims to religion as culture in Spain. Journal for the Scientific Study of Religion, 56(1), 126-142.

Azaryahu, M. (1996). The power of commemorative street names. Environment and Planning D: Society and Space, 14(3), 311-330.

Becci, I., Burchardt, M., \& Giorda, M. (2017). Religious super-diversity and spatial strategies in two European cities. Current Sociology, 65(1), 73-91.

Brauch, J., Lipphardt, A., \& Nocke, A. (2016). Jewish topographies: Visions of space, traditions of place. Aldershot: Ashgate and Routledge.

Burchardt, M., \& Westendorp, M. (2018). The immateriality of urban religion: Towards an ethnography of urban religious aspirations. Culture and Reli- gion, 19(2), 160-176.

Caballé, F., \& Gonzàlez, R. (2002). Recerca documental de la finca del carrer de l'Arc de Sant Ramon del Call núm. 8 de Barcelona [Documentary research of the urban estate in carrer de l'Arc de Sant Ramon del Call, house number 8, Barcelona]. Barcelona: Veclus SL. 2002.

Call Barcelona Wines \& Books. (2013). About. Facebook. Retrieved from https://www.facebook.com/ pg/callbarcelona/about/?ref=page_internal

Casals, J., \& Jáuregui, C. (2015). La història com a negoci: La falsa sinagoga major de Barcelona [History as business: The false Greater Synagogue of Barcelona]. Sàpiens. Retrieved from http://blogs.sapiens.cat/ medievalistesenbloc/2015/03/24/la-historia-com-anegoci

Charmé, S. Z. (2000). Varieties of authenticity in contemporary Jewish identity. Jewish Social Studies, 6(2), 133-155.

Clark, D. (1999). Creating Jewish spaces in European cities: Amnesia and collective memory. In J. Targarona Borrás \& A. Sáenz-Badillos (Eds.), Jewish studies at the turn of the twentieth century: Proceedings of the 6th EAJS Congress (pp. 274-281). Leiden, Köln and Boston, MA: Brill.

Clark, D. (2007). Sites of memory or aids to multiculturalism? Conflicting uses of Jewish heritage sites. Sociological Research Online, 12(2), 1-15.

Corsale, A. (2017). Jewish heritage tourism in Bucharest: Reality and visions. The Geographical Journal, 183(3), 261-271.

Corsale, A., \& Vuytsyk, O. (2018). Jewish heritage tourism between memories and strategies: Different approaches from Lviv, Ukraine. Current Issues in Tourism, 21(5), 583-598.

Dressler, M. (2019). Modes of religionization: A constructivist approach to secularity. Working Paper Series of the Centre for Advanced Studies "Multiple Secularities-Beyond the West, Beyond Modernities," 2019(7), 1-21. https://doi.org/10.36730/2020. 1.msbwbm.7

Eade, J. (2012). Religion, home-making and migration across a globalising city: Responding to mobility in London. Culture and Religion, 13(4), 469-483.

Endelstein, L. (2017). Lumières sur la ville. Les fêtes de Hanoucca entre action missionnaire transnationale et appartenance événementielle [Lights over the city. The Hanukkah celebrations, between transnational missionary action and event belonging]. Archives de Sciences Sociales des Religions, 2017(177), 51-71.

European Association for the Preservation and Promotion of Jewish Culture and Heritage. (2018). An easy preparation guide for the EDJC. Luxembourg: EAPJ. Retrieved from https://www.jewisheritage.org/ upload/edjc/pdf/invitation_to_join_edjc.pdf

Feliu, E. (2003). Salomó ben Adret, mestre de la llei jueva [Solomon ben Adret, master of Jewish law]. TAMID: Revista Catalana Anual d'Estudis Hebraics, 4(2002/2003), 35-109. 
Feliu, E. (2005). Sobre la lletra que Hasday Cresques adreçà a la comunitat jueva d'Avinyó parlant dels avalots de 1391 [About the letter that Hasday Cresques sent to the Avinyon Jewish community about the 1391 riots]. Tamid, 5(2004/2005), 171-219.

Feliu, E. (2009). Some clarifications on several aspects of the history of Jews in Medieval Catalonia. Catalan Historical Review, 2009, 49-64.

Festival Cinema Jueu de Barcelona. (2019). About us. Festival Cinema Jueu de Barcelona. Retrieved from https://fcjbarcelona.org/en/about-us

Graham, B. (2002). Heritage as knowledge: Capital or culture? Urban Studies, 39(5/6), 1003-1017.

Greater Synagogue of Barcelona. (2020). Synagogue. Greater Synagogue of Barcelona. Retrieved from https://www.sinagogamayor.com/en/sinagoga

Gruber, R. E. (2002). Virtually Jewish: Reinventing Jewish culture in Europe. Berkeley, CA: University of California Press.

Hames, H. J. (2010). A Jew amongst Christians and Muslims: Introspection in Solomon ibn Adret's response to ibn Hazm. Mediterranean Historical Review, 25(02), 203-219.

Kearney, A., \& Bradley, J. J. (2009). 'Too strong to ever not be there': Place names and emotional geographies. Social \& Cultural Geography, 10(1), 77-94.

Kirshenblatt-Gimblett, B. (1998). Destination culture: Tourism, museums, and heritage. Berkeley, CA: University of California Press.

Krakover, S. (2012). Coordinated marketing and dissemination of knowledge: Jewish heritage tourism in Serra Da Estrela, Portugal. Revista Turismo \& Desenvolvimento, 1(17/18), 11-16.

Krakover, S. (2013). Generation of a tourism product: Jewish heritage tourism in Spain. Enlightening Tourism. A Pathmaking Journal, 3(2), 142-168.

Lehrer, E., \& Meng, M. (2015). Jewish space in contemporary Poland. Bloomington, IN: Indiana University Press.

Martínez-Ariño, J. (2012a). Las comunidades judías contemporáneas de Cataluña. Un estudio sociológico a través de los procesos de construcción y transmisión identitaria [The contemporary Jewish communities of Catalonia: A sociological study through the identity construction and transmisson processes] (Unpublished Doctoral dissertation). Autonomous University of Barcelona, Barcelona, Spain. Retrieved from https://www.tdx.cat/handle/10803/113490

Martínez-Ariño, J. (2012b). Identidades y vivencias judías en la Cataluña contemporánea: Una realidad diversa y cambiante [Jewish identities and experiences in contemporary Catalonia: A diverse and changing reality]. Quaderns-e de l'Institut Català d'Antropologia, 17(2), 73-85.

Martínez-Ariño, J. (2016). "Being Jew is like travelling by bus": Constructing Jewish identities in Spain between individualisation and group belonging. Journal of Religion in Europe, 9(4), 324-349.
Negussie, E. (2007). Managing conservation of the built heritage in post-socialist Budapest: Evidence from the old Jewish quarter. International Journal of Heritage Studies, 13(2), 136-156.

Petrevska, B., Krakover, S., \& Collins-Kreiner, N. (2018). Preserving cultural assets of others: Jewish heritage sites in Macedonian cities. Tourism Geographies, 20(3), 549-572.

Pin, G. (2018, October 8). A vegades escric textos de llocs pels que passem estant a l'Ajuntament, sovint no els publico, però aquest el volia compartir. SUKKOT [Sometimes I write texts about the places we visit while in the municipal government, I often don't publish them, but this one I wanted to share. SUKKOT; Facebook status update]. Retrieved from https://www.facebook.com/gala.pin1/ posts/1832663183514050

Pons i Casacuberta, X. (2010). La Comissió creada pel Rei Joan I i la Reina Violant a partir dels pogroms contra els jueus de 1391. Espoliació del capital i patrimoni dels jueus i conversos [The Commission created by King Joan and Queen Violant from the pogroms against the Jews of 1391. Spoliation of capital and assets of Jews and converts]. Acta historica et archaeologica mediaevalia, 30, 119-152.

Rich Abad, A. R. (1999). La comunitat jueva de Barcelona, segle XIV [The Barcelona Jewish community, 14th century]. Butlletí de la Societat Catalana d'Estudis Històrics, 10, 53-56.

Richards, S. L. (2005). What is to be remembered? Tourism to Ghana's slave Castle-Dungeons. Theatre Journal, 57(4), 617-637.

Rose-Redwood, R., Alderman, D., \& Azaryahu, M. (2010). Geographies of toponymic inscription: New directions in critical place-name studies. Progress in $\mathrm{Hu}$ man Geography, 34(4), 453-470.

Rozenberg, D. (2010). La España contemporánea y la cuestión judía [Contemporary Spain and the Jewish issue]. Madrid: Casa Sefarad-Israel.

Saint-Blancat, C., \& Cancellieri, A. (2014). From invisibility to visibility? The appropriation of public space through a religious ritual: The Filipino procession of Santacruzan in Padua, Italy. Social \& Cultural Geography, 15(6), 645-663.

Sells, M. (2003). Crosses of blood: Sacred space, religion, and violence in Bosnia-Hercegovina. Sociology of Religion, 64(3), 309-331.

Shoval, N. (2013). Street-naming, tourism development and cultural conflict: The case of the old city of Acre/Akko/Akka. Transactions of the Institute of British Geographers, 38(4), 612-616.

Sinha, V. (2016). Marking spaces as 'sacred': Infusing Singapore's urban landscape with sacrality. International Sociology, 31(4), 467-488.

Smith, L. (2006). Uses of heritage. London and New York, NY: Routledge.

Umashankar, R. R. (2015). Metropolitan microcosms: The dynamic spaces of contemporary Sufi shrines in India. 
South Asian Studies, 31(1), 127-143.

Urban Cultours. (2002). About Urban Cultours project. Urban Coultours. Retrieved from http://www. urbancultours.com/Pages/eng/about_us.html

Vásquez, M. A., \& Knott, K. (2014). Three dimensions of religious place making in diaspora. Global Networks,
14(3), 326-347.

Zubrzycki, G. (2012). Religion, religious tradition, and nationalism: Jewish revival in Poland and 'religious heritage' in Québec. Journal for the Scientific Study of Religion, 51(3), 442-455.

\section{About the Author}

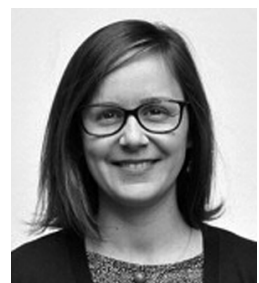

Julia Martínez-Ariño is Assistant Professor of Sociology of Religion at the University of Groningen. Her research interests are the governance of religious diversity, the spatial strategies of religious groups and non-religion. She has published in journals such as Current Sociology and Social Compass. Martínez-Ariño convenes the "Religion and Cities" research cluster of the Centre for Religion, Conflict and Globalization at the University of Groningen and is Associate Researcher for the ISOR research group at the Autonomous University of Barcelona. 